Check for updates

Cite this: RSC Adv., 2019, 9, 1831

\title{
Silver ferrite: a superior oxidizer for thermite-driven biocidal nanoenergetic materials $\uparrow$
}

\begin{abstract}
Tao Wu (D) and Michael R. Zachariah (D)*
Silver-containing oxidizers are of interest as biocidal components in energetic application such as thermites due to their biocidal agent delivery. In this study, $\mathrm{AgFeO}_{2}$, was evaluated as an oxidizer in aluminum-based thermite system. This novel oxidizer $\mathrm{AgFeO}_{2}$ particles were prepared via a wet-chemistry method and its structure, morphologies and thermal behavior were investigated using X-ray diffraction, scanning electron microscopy, thermogravimetric analysis and differential scanning calorimetry, and time-resolved temperature-jump time-of-flight mass spectrometry. The results indicate the decomposition pathways of $\mathrm{AgFeO}_{2}$ vary with heating rates from a two-step at low heating rate to a single step at high heating rate. Ignition of $\mathrm{Al} / \mathrm{AgFeO}_{2}$ occurs at a temperature just above the oxygen release temperature that is very similar to $\mathrm{Al} / \mathrm{Fe}_{2} \mathrm{O}_{3}$ and $\mathrm{Al} / \mathrm{CuO}$. However, with a pressurization rate three times of $\mathrm{Al} / \mathrm{CuO}, \mathrm{Al}$ $\mathrm{AgFeO}_{2}$ yields a comparable result as to $\mathrm{Al} /$ hollow- $\mathrm{CuO}$ or $\mathrm{Al} / \mathrm{KClO}_{4} / \mathrm{CuO}$, with a simpler preparation method. The post combustion products demonstrated that the $\mathrm{Al} / \mathrm{AgFeO}$ thermite reaction produces a fine dispersion of elemental nanosized silver particles which coats the larger alumina particles and is thus bioavailable.
\end{abstract}

Received 30th October 2018 Accepted 13th December 2018

DOI: $10.1039 / \mathrm{c} 8 \mathrm{ra0} 8997 \mathrm{c}$

rsc.li/rsc-advances adopted metal is aluminum due to its abundance and competitive reactivity when compared with other metals. ${ }^{\mathbf{1 6}}$ Various oxidizers, such as metal oxides, ${ }^{17-26}$ iodine oxides, ${ }^{27-32}$ sulfates, ${ }^{33,34}$ iodates, ${ }^{12,35,36}$ potassium salts, ${ }^{37,38}$ and etc., have been employed in formulation of thermites. Among all, halogens-containing and silver-containing oxidizers have drawn attention because of their excellent biocidal properties. ${ }^{39-43}$ For halogens, iodine stands out owing to its strong neutralization effect and different iodine-containing oxy-compounds, such as metal iodates and iodine oxides, ${ }^{5,12,18-25,27-33,35-37,44}$ have been studied in thermite systems.

As to silver, it has been pointed out that silver exhibits biocidal properties in the forms of metallic $\mathrm{Ag}$ particles and silver ions in a humid environment. ${ }^{45}$ Since most of the products of thermite combustion tend to be primarily in the condensed phase ${ }^{2}$ metallic silver particles are the focus of this work. As indicated by Morones et al. ${ }^{46}$ and Smetana et al., ${ }^{47}$ small particle sizes are necessary for silver particles to perform well in biocidal activities. To deliver not only a high thermal event but also a large amount of small silver particles as the active biocidal sites is the goal of this work.

When it comes to silver-containing oxidizers, $\mathrm{Ag}_{2} \mathrm{O}$ was the obvious choice to be considered as an oxidizer in an aluminumbased thermite system. In 2010, Clark et al. ${ }^{48}$ investigated the combustion performance and biocidal abilities of both $\mathrm{Al} / \mathrm{I}_{2} \mathrm{O}_{5}$ and $\mathrm{Al} / \mathrm{Ag}_{2} \mathrm{O}$ thermites using a homemade biocidal reaction chamber. They concluded $\mathrm{Al} / \mathrm{I}_{2} \mathrm{O}_{5}$ thermite exhibited significant spore neutralization owing to the generation of lot of iodine gas. In 2011, Russell et al. ${ }^{49}$ further studied the flame propagation
Department of Chemistry and Biochemistry, Department of Chemical and Biomolecular Engineering, University of Maryland, College Park, MD 20742, USA. E-mail:mrz@umd.edu

$\dagger$ Electronic supplementary information (ESI) available. See DOI: 10.1039/c8ra08997c 
behaviors of $\mathrm{Al} / \mathrm{I}_{2} \mathrm{O}_{5}$ and $\mathrm{Al} / \mathrm{Ag}_{2} \mathrm{O}$ thermites using mechanical impact and thermal initiation. The results show that $\mathrm{Al} / \mathrm{Ag}_{2} \mathrm{O}$ features a lower average flame propagation by about 2.5 times in thermal ignition tests but produce much more energy than $\mathrm{Al}$ / $\mathrm{I}_{2} \mathrm{O}_{5}$ in impact-driven ignition tests. They also argued that the energy release of the thermite reactions is significantly enhanced by reducing the sizes of the oxidizers particles. In the same year, Sullivan et al. ${ }^{5}$ investigated the performance of $\mathrm{AgIO}_{3}$ as an oxidizer in aluminum-based thermite because it decomposed to $\mathrm{O}_{2}$, $\mathrm{O}$ and $\mathrm{I}$ gases when heated at an ultra-high heating rate. Silver was not observed in the mass spectra probably because the temperature was not high enough to reach the adiabatic flame temperature and thus could not vaporize silver. However, $\mathrm{Al} / \mathrm{AgIO}_{3}$ considerably outperformed $\mathrm{Al} / \mathrm{CuO}$ in pressurization rate due to a large number of gaseous products released from $\mathrm{AgIO}_{3}$; however, its high combustion performance was mitigated by the fact that the reaction products were found to form AgI instead of elemental silver and iodine, thus obstructing its usage in biocidal applications.

Sullivan et al. ${ }^{2}$ subsequently synthesized nano- $\mathrm{Ag}_{2} \mathrm{O}$ particles and investigated its reactivity as an oxidizer in biocidal energetic systems since it produces high yields of antimicrobial silver as one of the combustion products. They found that $\operatorname{Ag}_{2} \mathrm{O}$ alone performs poorly in terms of pressurization rate and burn time, but its performance is significantly improved when combined with one more reactive oxidizer, such as $\mathrm{AgIO}_{3}$ or $\mathrm{CuO}$. The morphology of the final products was also studied and indicated that abundant active sites of silver particles were sacrificed since some silver particles were trapped within the interior of other products, which might to some extent affect its biocidal activity. Inspired by the fact that $\mathrm{CuO}$ addition improves the performance of $\mathrm{Al} / \mathrm{Ag}_{2} \mathrm{O}$ significantly, we embed the extra oxidizer into $\mathrm{Ag}_{2} \mathrm{O}$ molecularly in this work. Since we have some experience on ferrite-type oxides $\left(\mathrm{AFeO}_{4}\right)$ and delafossite-type oxides $\left(\mathrm{ABO}_{2}\right)$ previously, $\mathrm{AgFeO}_{2}$ as a molecularly mixed oxidizer of $\mathrm{Ag}_{2} \mathrm{O}$ and $\mathrm{Fe}_{2} \mathrm{O}_{3}$ with a delafossite structure was a good choice. In addition, $\mathrm{Fe}_{2} \mathrm{O}_{3}$ has been proven to be a poor oxidizer in Al-based thermite system, ${ }^{37}$ it could be of significant interest if $\mathrm{AgFeO}_{2}$ which comprises two poor oxides $\left(\mathrm{Ag}_{2} \mathrm{O}\right.$ and $\left.\mathrm{Fe}_{2} \mathrm{O}_{3}\right)$ became a strong oxidizer.

A wet-chemistry method was adopted here for the preparation of $\mathrm{AgFeO}_{2}$ and its thermal behavior were investigated using a low heating rate thermogravimetric analysis and differential scanning calorimetry in an argon environment. Time-resolved temperature-jump time-of-flight mass spectrometry (T-Jump/ TOFMS) was also employed to evaluate the decomposition behaviors of bare $\mathrm{AgFeO}$ or $\mathrm{Al} / \mathrm{AgFeO}_{2}$ thermites under rapid heating rates, enabling us to probe the reaction process on a time scale close to that of a combustion event. The results indicate that the decomposition pathways of $\mathrm{AgFeO}_{2}$ vary in term of heating rates. For a comparison purpose, $\mathrm{Al} / \mathrm{CuO}, \mathrm{Al} /$ $\mathrm{Ag}_{2} \mathrm{O}$ and $\mathrm{Al} / \mathrm{Ag}_{2} \mathrm{O} / \mathrm{Fe}_{2} \mathrm{O}_{3}$ were also included in this work. A highspeed camera coupled with T-Jump/TOFMS simultaneously captured optical emission from the ignition/reaction of the thermites allowing us to obtain the ignition time, and corresponding ignition temperature. In addition, constant volume combustion cell tests were performed on aluminum-based thermites. The post combustion products were characterized by X-ray diffraction, scanning electron microscopy, transmission electron microscopy and energy-disperse X-ray spectroscopy. The results demonstrated that the $\mathrm{Al} / \mathrm{AgFeO}_{2}$ thermite reaction produce an enormous amount of nanosized silver particles and feature the best combustion performance in this work.

\section{Materials and characterizations}

\section{Materials}

The aluminum nanopowders (Al) (Alex, $\sim 80 \mathrm{~nm}$ ) was purchased from Novacentrix. The active $\mathrm{Al}$ was $81 \%$ by mass, determined by TGA. All metal oxide nanopowders $(<50 \mathrm{~nm})$ purchased from Sigma-Aldrich was directly used as received. All the other chemicals were of analytical grade and used as purchased without further treatment.

\section{Preparation of $\mathrm{AgFeO}_{2}$}

$\mathrm{AgFeO}_{2}$ powders were prepared via a co-precipitation method. For this, $2.66 \mathrm{mmol}$ of $\mathrm{Fe}\left(\mathrm{NO}_{3}\right)_{3} \cdot 9 \mathrm{H}_{2} \mathrm{O}$ and $2.66 \mathrm{mmol}$ of $\mathrm{AgNO}_{3}$ were dissolved in $20 \mathrm{~mL}$ of water and stirred for 30 minutes. The solution was then heated to $80{ }^{\circ} \mathrm{C}$ and stirred for one hour. Then, $1.5 \mathrm{M}$ of $\mathrm{NaOH}$ solution was added dropwise into the solution until its $\mathrm{pH}$ reaches 13 , followed by another 6 hours of stirring on a hot plate $\left(80^{\circ} \mathrm{C}\right)$. The prepared $\mathrm{AgFeO}_{2}$ powders could be easily isolated from the solution by vacuum filtration and were purified by successively washing with copious amount of distilled water and absolute ethanol. Finally, the product was dried in an oven at $70{ }^{\circ} \mathrm{C}$.

\section{Preparation of $\mathrm{Ag}_{2} \mathrm{O}$}

$\mathrm{Ag}_{2} \mathrm{O}$ powders were prepared by adding $0.025 \mathrm{M} \mathrm{NaOH}$ solution dropwise into $80 \mathrm{~mL}$ of $\mathrm{AgNO}_{3}$ solution (0.005 M) with stirring until the solution become a grey-yellow colloidal suspension. The suspension was kept at $60{ }^{\circ} \mathrm{C}$ for another 2 hours to ensure complete reaction. The prepared $\mathrm{Ag}_{2} \mathrm{O}$ powders were collected by centrifugation and washed with distilled water and then absolute ethanol three times. The solid pure $\mathrm{Ag}_{2} \mathrm{O}$ was obtained after being dried in an oven at $70{ }^{\circ} \mathrm{C}$ for 10 hours.

\section{Preparation of thermites}

Aluminum nanopowders was stoichiometric mixed with $\mathrm{AgFeO}{ }_{2}, \mathrm{Ag}_{2} \mathrm{O}$, CuO and $\mathrm{Fe}_{2} \mathrm{O}_{3}$ based on the following equations, respectively, in dry hexane followed by 30 minutes sonication (Table 1). After room temperature evaporation of the solvent the solid thermite powders were collected.

\section{T-Jump/TOFMS measurement and high-speed imaging}

The decomposition of oxides particles was investigated using a custom T-Jump/TOFMS ${ }^{5}$ Typically, a $\sim 1 \mathrm{~cm}$ long platinum wire (76 $\mu \mathrm{m}$ in width) with a thin coating of oxidizer or thermite sample was rapidly joule-heated to about $1200{ }^{\circ} \mathrm{C}$ by a $3 \mathrm{~ms}$ pulse at a heating rate of $\sim 10^{5}{ }^{\circ} \mathrm{C} \mathrm{s}^{-1}$. The current and voltage signals were recorded, and the temporal temperature on the 
Table 1 Calculated heat of reaction of thermite reactions ${ }^{a}$

\begin{tabular}{ll}
\hline Thermite reaction & $\begin{array}{l}\text { Heat of reaction } \\
\left(\mathrm{cal} \mathrm{g}^{-1}\right)\end{array}$ \\
\hline $2 \mathrm{Al}+3 \mathrm{Ag}_{2} \mathrm{O} \rightarrow 6 \mathrm{Ag}(\mathrm{l}, \mathrm{g})+\mathrm{Al}_{2} \mathrm{O}_{3}(\mathrm{l})$ & 504.8 \\
$2 \mathrm{Al}+3 \mathrm{CuO} \rightarrow 3 \mathrm{Cu}(\mathrm{l}, \mathrm{g})+\mathrm{Al}_{2} \mathrm{O}_{3}(\mathrm{l})$ & 974.1 \\
$2 \mathrm{Al}+\mathrm{Fe}_{2} \mathrm{O}_{3} \rightarrow 2 \mathrm{Fe}(\mathrm{l}, \mathrm{g})+\mathrm{Al}_{2} \mathrm{O}_{3}(\mathrm{l})$ & 945.4 \\
$4 \mathrm{Al}+3 \mathrm{AgFeO}$ & $\rightarrow 3 \mathrm{Ag}+3 \mathrm{Fe}+2 \mathrm{Al}_{2} \mathrm{O}_{3}(\mathrm{l})$ \\
${ }^{a}$ The thermodynamic data of $\mathrm{AgFeO}_{2}$ is unknown. Data is taken from \\
Fischer and Grubelich ${ }^{50}$ without taking account of the oxide shell on \\
aluminum.
\end{tabular}

wire was measured according to the Callendar-Van Dusen equation. MS spectra were measured every $0.1 \mathrm{~ms}$. The detailed experimental set-up is given in our previous papers..$^{5,33}$

To identify the point of ignition a high-speed camera (Vision Research Phantom v12.0) was employed to record the combustion on the wire during heating. Ignition temperatures of thermite reactions in vacuum were measured from the correlation of optical emission from high speed imaging and temporal temperature of the wire and were further analyzed in combination with the temporal mass spectra. Each experiment was repeated 3 times.

\section{X-ray diffraction (XRD) measurement and Rietveld refinement}

The as-prepared samples were characterized by powder X-ray diffraction. Diffraction pattern was measured using $\mathrm{Cu} \mathrm{K} \alpha$ radiation in Bragg-Brentano geometry on Bruker D8 Advance powder diffractometer equipped with incident beam Soller slits, Ni $\beta$-filter and LynxEye position sensitive detector. Data were collected from $10^{\circ}$ to $90^{\circ} 2 \theta$ with a step size of $0.01578^{\circ}$ and counting time of $1 \mathrm{~s}$ per step (total exposure time of $180 \mathrm{~s}$ per step).

\section{Thermogravimetric analysis/differential scanning calorimetry} (TGA/DSC) measurement

Thermogravimetric analysis and differential scanning calorimetry (TGA/DSC) was performed using a TA Instruments SDT Q600. The analysis was performed under a $100 \mathrm{~mL} \mathrm{~min}^{-1}$ argon flow with $\sim 1.0 \mathrm{mg}$ samples placed into an alumina pan and heated from room temperature up to $1000{ }^{\circ} \mathrm{C}$ at a rate of $10{ }^{\circ} \mathrm{C} \min ^{-1}$ in argon atmosphere.

\section{Morphologies and structures characterizations transmission electronic microscopy (TEM)}

Transmission electronic microscopy (TEM, JEOL JEM 2100 FEG) and scanning electronic microscopy (SEM, Hitachi Su-70) were used to investigate morphologies and structures of thermites. Elemental distribution in the thermites was analyzed by Energydisperse X-rat spectroscopy (EDS) on both SEM and TEM.

\section{Combustion test}

Combustion properties of themites were evaluated in a constant-volume combustion cell, with simultaneous pressure and optical emission measurements. In this study, $25 \mathrm{mg}$ of thermite powders was loaded inside the cell (constant volume, $\sim 13 \mathrm{~cm}^{3}$ ) and ignited by a resistively heated nichrome wire. The temporal pressure and optical emission from the thermite reaction were measured using a piezoelectric pressure sensor and a photodetector, respectively. More detailed information on the combustion cell test can be found in our previous publications. ${ }^{21,25,30}$ Each experiment was repeated at least 3 times.

\section{Results and discussions}

\section{Synthesis and characterization of $\mathrm{AgFeO}_{2}$}

XRD of as-prepared materials shown in Fig. 1A indicates that silver ferrite was successfully prepared. The particles have an oval shape with particle size of $\sim 40 \mathrm{~nm}$ based on the SEM image shown in Fig. 1B, and suggests it might be a very good oxidizer in a thermite system due to its small size. ${ }^{33}$

The thermal stability of $\mathrm{AgFeO}_{2}$ was studied with a TGA in $\mathrm{Ar}$ at a heating rate of $10{ }^{\circ} \mathrm{C} \mathrm{min}^{-1}$. The result shown in Fig. 2 indicates a $\sim 4 \%$ weigh loss at around $650{ }^{\circ} \mathrm{C}$, corresponding to $\mathrm{O}_{2}$ gas release based on eqn (1). To determine the composition of the remaining material, XRD shown in Fig. $2 \mathrm{~B}$ indicates the formation of both $\mathrm{Fe}_{2} \mathrm{O}_{3}$ and $\mathrm{Ag}$.

$$
2 \mathrm{AgFeO}_{2} \rightarrow 2 \mathrm{Ag}+\mathrm{Fe}_{2} \mathrm{O}_{3}+1 / 2 \mathrm{O}_{2}
$$
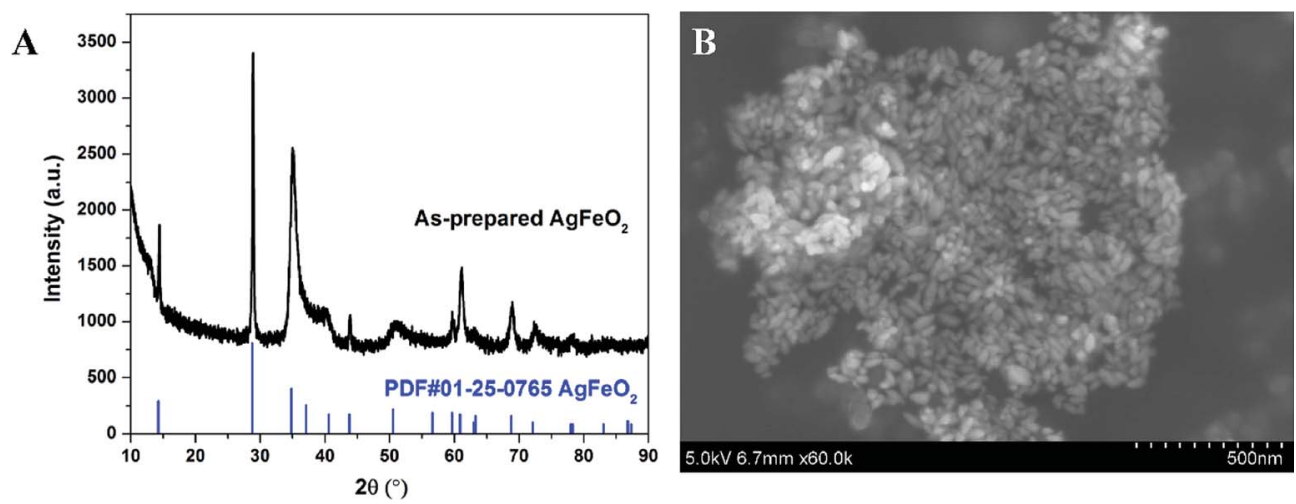

Fig. 1 XRD spectrum (A) and SEM image (B) of $\mathrm{AgFeO}_{2}$ prepared via co-precipitation. 

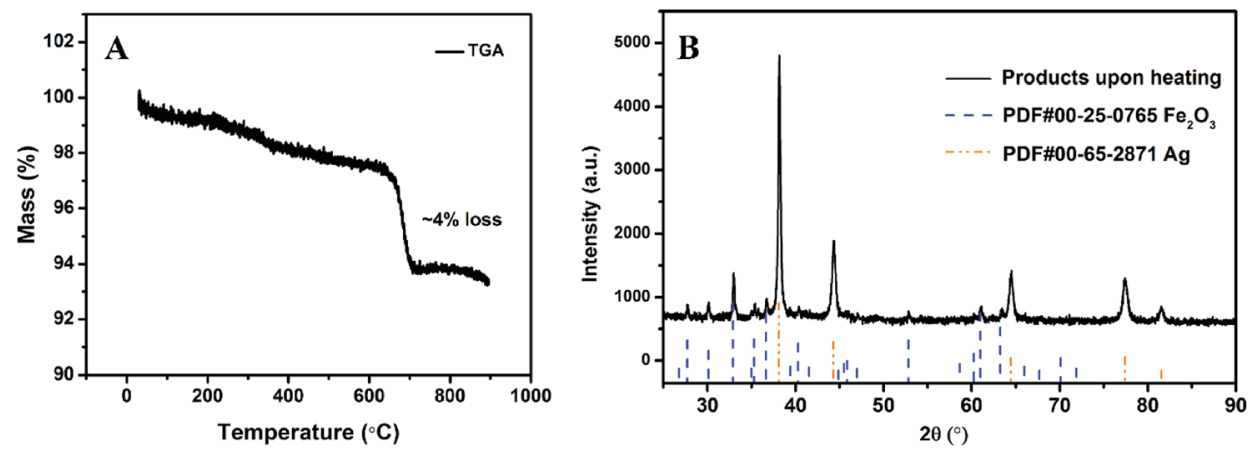

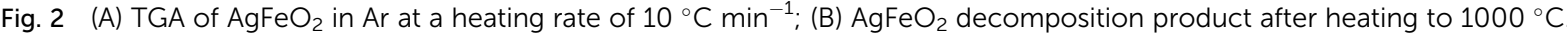

High heating rate decomposition of $\mathrm{AgFeO}_{2}$ was investigated using TOFMS/T-Jump ( $3 \mathrm{~ms}$, heating rate $\left.\sim 5 \times 10^{5}{ }^{\circ} \mathrm{C} \mathrm{s}^{-1}\right)$. Fig. 3 shows the temporal evolution of $\mathrm{O}_{2}$ from $\mathrm{AgFeO}_{2}$ during rapid heating. Oxygen was first detected at around $685^{\circ} \mathrm{C}$ which is slightly higher than the onset decomposition temperature under low heating rate TGA. Only one $\mathrm{O}_{2}$ signal stage is observed indicating the decomposition of $\mathrm{AgFeO}_{2}$ is a one-step event at high heating rates conditions, as compared to its multistage decomposition behavior at low heating rates as discussed previously.

Time-resolved T-Jump mass spectra from rapid heating of $\mathrm{AgFeO}_{2}$ at 1.6-2.2 ms is shown in Fig. $\mathrm{S} 1 \dagger$ to further explore its decomposition process. Apparently, the onset decomposition of $\mathrm{AgFeO}_{2}$ started at around $1.8 \mathrm{~ms}\left(685^{\circ} \mathrm{C}\right)$ with the appearance of a small $\mathrm{O}_{2}$ peak. For mass spectra taken at prior times, $\mathrm{H}_{2} \mathrm{O}^{+}$, $\mathrm{OH}^{+}, \mathrm{CO}^{+} / \mathrm{N}_{2}{ }^{+}$peaks are attributed to the background..$^{18}$ Above the decomposition temperature, no new peak except for $\mathrm{O}_{2}$ peak is found again suggests a one-step decomposition of $\mathrm{AgFeO}_{2}$ at high heating rate. $\mathrm{CO}_{2}{ }^{+}$was also observed which we attribute to decomposition products of the precursor salt residue on the $\mathrm{AgFeO}_{2}$ surface. $^{17}$

\section{Ignition of $\mathrm{Al} / \mathrm{AgFeO}_{2}$ nanothermite}

To evaluate the performance of $\mathrm{AgFeO}_{2}$ as an oxidizer in Albased thermite, physical mixtures of nanosized aluminum and $\mathrm{AgFeO}_{2}$ were made, following $30 \mathrm{~min}$ sonication of the

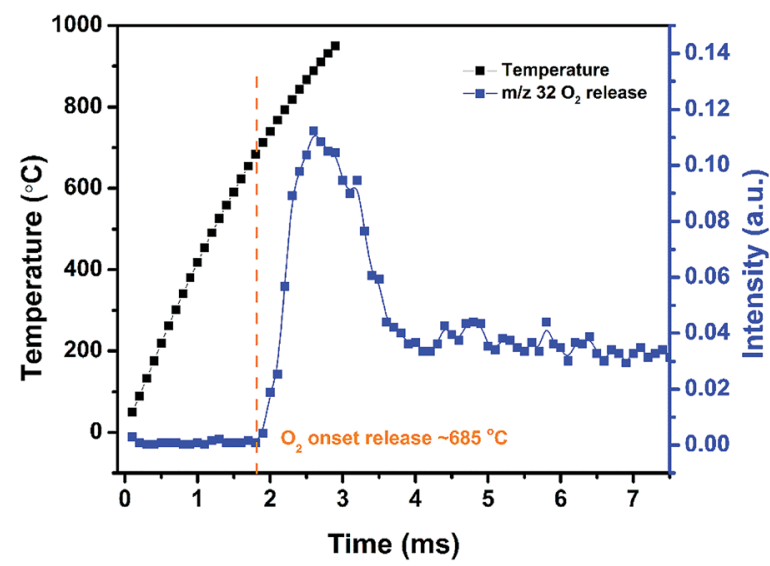

Fig. 3 Temperature and $\mathrm{O}_{2}$ temporal profile of $\mathrm{AgFeO}_{2}$. mixture in dry hexane. Sequential snapshot of $\mathrm{Al} / \mathrm{AgFeO}_{2}$ ignition during high-rate heating under vacuum were captured using a high-speed camera and is shown in Fig. 4. Optical emission from $\mathrm{Al} / \mathrm{AgFeO}_{2}$ reaction was first observed at 1.662 ms with a corresponding wire temperature of $\sim 740^{\circ} \mathrm{C}$ as a sign of ignition. Multiple ignition points are observed in the prior time and then merge into a large bright flame. One should also notice that, upon ignition, thousands of bright dots were rapidly ejected out from the reactants coated on the Pt wire (even more bright dots appeared when ignited in an argon environment as shown in Fig. S2 $\dagger$ ). The burn time of the thermite in T-Jump chamber could be roughly obtained based on the visual flame and is about $0.3 \mathrm{~ms}$, which is almost the same as the value obtained from the combustion cell test discussed below.

$\mathrm{Ag}_{2} \mathrm{O}$ was included as an oxidizer in $\mathrm{Al}$-based thermites as a control. As the most common used oxidizer, $\mathrm{CuO}$ was also included as a standard reference. Since $\mathrm{AgFeO}_{2}\left(\mathrm{Ag}_{2} \mathrm{Fe}_{2} \mathrm{O}_{4}\right)$ can be molecularly written as $\mathrm{Ag}_{2} \mathrm{O}$ and $\mathrm{Fe}_{2} \mathrm{O}_{3}$, a binary mixture $\mathrm{Ag}_{2} \mathrm{O}-\mathrm{Fe}_{2} \mathrm{O}_{3}$ with $1 / 1$ molar ratio is also included for comparison.

Fig. 5 shows the relationship between $\mathrm{O}_{2}$ release temperature in neat oxides and the ignition temperature of corresponding thermites under vacuum. There is a good correlation between the oxygen release from the bare oxidizer and ignition of $\mathrm{Al} /$ $\mathrm{CuO}, \mathrm{Al} / \mathrm{Fe}_{2} \mathrm{O}_{3}$ and $\mathrm{Al} / \mathrm{AgFeO}{ }_{2} . \mathrm{Al} / \mathrm{Fe}_{2} \mathrm{O}_{3}$ has a very high ignition temperature due to the poor performance of $\mathrm{Fe}_{2} \mathrm{O}_{3}$ as an oxidizer. ${ }^{24}$ On the other hand, $\mathrm{Al} / \mathrm{Ag}_{2} \mathrm{O}$ thermite ignited at around $\sim 660{ }^{\circ} \mathrm{C}$, essentially the melting temperature of aluminum. Considering $\mathrm{Ag}_{2} \mathrm{O}$ releases oxygen at around $520{ }^{\circ} \mathrm{C}$, it is reasonable to conclude that the ignition of $\mathrm{Al} / \mathrm{Ag}_{2} \mathrm{O}$ thermite is limited to the melting phase of aluminum like most $\mathrm{Al} / \mathrm{metal}$ oxides systems. ${ }^{19}$ In fact, the ignition temperatures of the other four samples are all higher than the melting point of aluminum indicates that gaseous oxygen released from the decomposition of oxidizers, was insufficient to ignite aluminum when it is still in the solid phase.

$\mathrm{Al} / \mathrm{Ag}_{2} \mathrm{O} / \mathrm{Fe}_{2} \mathrm{O}_{3}$ ternary thermite ignited at around $800{ }^{\circ} \mathrm{C}$ much higher than its oxygen release temperature $\left(520{ }^{\circ} \mathrm{C}\right)$. Considering $\mathrm{Al} / \mathrm{Ag}_{2} \mathrm{O}$ and $\mathrm{Al} / \mathrm{Fe}_{2} \mathrm{O}_{3}$ ignited at around 660 and $940{ }^{\circ} \mathrm{C}$, respectively, an ignition temperature of about $800{ }^{\circ} \mathrm{C}$ is reasonable for the ternary system $\mathrm{Al} / \mathrm{Ag}_{2} \mathrm{O} / \mathrm{Fe}_{2} \mathrm{O}_{3}$. The $\mathrm{Fe}_{2} \mathrm{O}_{3}$ addition is more likely hindering/weakening the ignition/ 


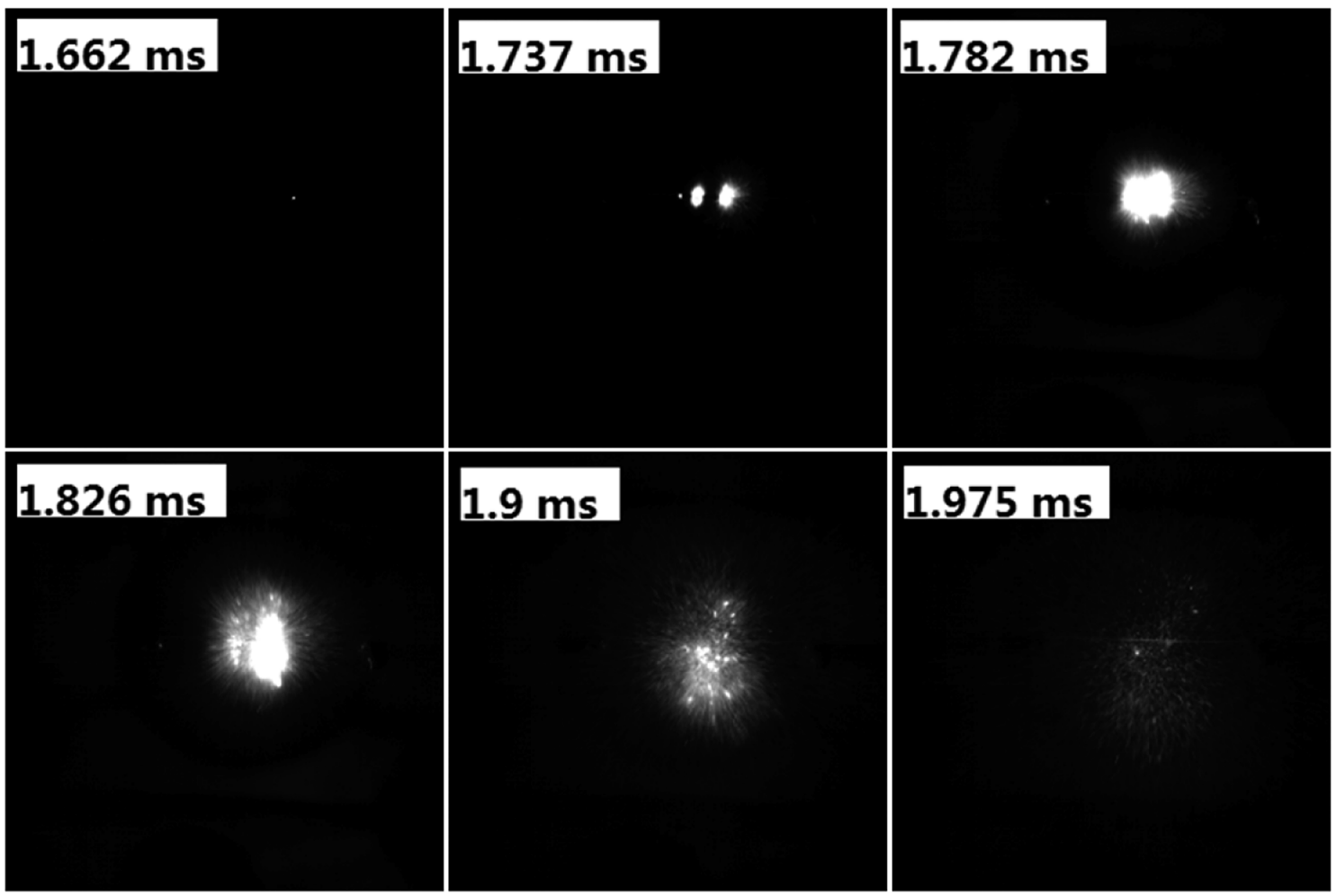

Fig. 4 Sequential snapshots of $\mathrm{Al} / \mathrm{AgFeO}_{2}$ burning on a high-rate heating Pt wire in T-Jump chamber (in vacuum). The labels in each image are the time elapse after triggering.

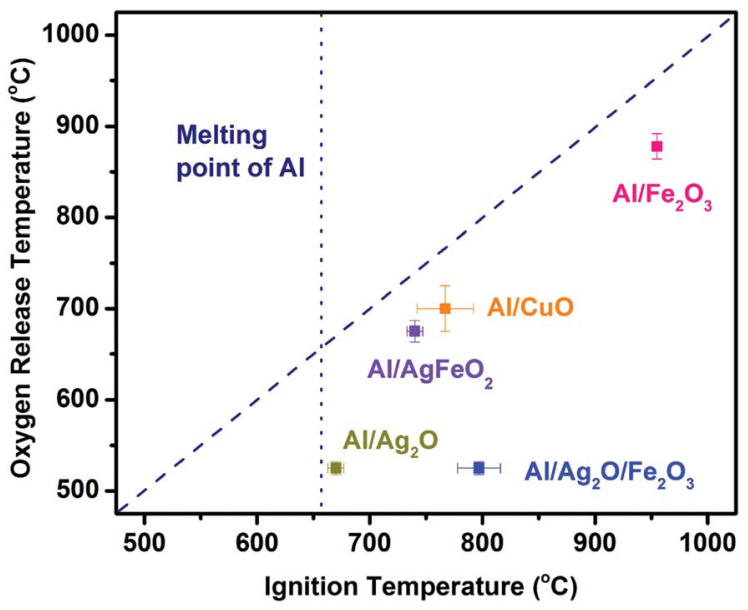

Fig. 5 Ignition temperature vs. oxygen release temperature from the corresponding oxidizer. The diagonal dash line presents a perfect correlation.

reaction of the ternary system due to its weak reactivity in Albased thermites. ${ }^{37}$

As to $\mathrm{Al} / \mathrm{AgFeO}_{2}$, it ignited at a temperature close to the oxygen release temperature of the corresponding oxidizer and higher than the melting temperature of aluminum following an ignition mechanism similar to $\mathrm{Al} / \mathrm{Fe}_{2} \mathrm{O}_{3}$ and $\mathrm{Al} / \mathrm{CuO} .{ }^{18,19}$ Moreover, the fact that the ignition temperature of $\mathrm{Al} / \mathrm{Fe}_{2} \mathrm{O}_{3}$ is much higher than that of $\mathrm{Al} / \mathrm{AgFeO}{ }_{2}$ implies the oxygen involved with $\mathrm{Al} / \mathrm{AgFeO}_{2}$ ignition come from $\mathrm{AgFeO}_{2}$ rather than the first-stage decomposed product $\mathrm{Fe}_{2} \mathrm{O}_{3}$ as indicated in TGA. Since only one oxygen release stage appeared at the mass spectra and the violent reaction of $\mathrm{Al} / \mathrm{AgFeO}_{2}$ at $1.7 \mathrm{~ms}\left(\sim 780{ }^{\circ} \mathrm{C}\right)$ implies decomposition of $\mathrm{AgFeO}_{2}$ is a one-step process during $\mathrm{Al}$ / $\mathrm{AgFeO}_{2}$ thermite reaction at high heating rate.

\section{Combustion performance of $\mathrm{Al} / \mathrm{AgFeO}_{2}$ nanothermite}

The combustion performance of $\mathrm{Al} / \mathrm{AgFeO}$ at room atmosphere was studied using a constant volume combustion cell, and the results are summarized in Table 2 . The pressurization rate and peak pressure in $\mathrm{Al} / \mathrm{AgFeO}_{2}$ reaction are $6200 \mathrm{kPa} \mathrm{ms}^{-1}$ and 325 $\mathrm{kPa}$, respectively, which are considerably higher than those of nano-thermite reaction of $\mathrm{Al} / \mathrm{CuO}$. A direct comparison between the temporal pressure traces of $\mathrm{Al} / \mathrm{AgFeO}_{2}$ and $\mathrm{Al} / \mathrm{CuO}$ was shown in Fig. 6A in which the first peak was used to determine the corresponding pressurization rate. Clearly, $\mathrm{Al} / \mathrm{AgFeO}{ }_{2}$ reaction reaches its first peak with a faster rate and higher peak value compared with $\mathrm{Al} / \mathrm{CuO}$. We have claimed in our previous works that gaseous species release from the decomposition of the oxidizer is the main cause for the pressurization, which can occur much earlier than ignition/combustion. ${ }^{37,51}$ The fact that $\mathrm{AgFeO}_{2}(\sim 16 \%)$ has a lower oxygen weight ratio than $\mathrm{CuO}$ $(\sim 20 \%)$ suggests the $\mathrm{O}_{2}$ release rate of $\mathrm{AgFeO}_{2}$ must be higher than that of $\mathrm{CuO}$ in order to output such high pressure. In addition, the optical signals peak much later than the corresponding pressure peaks for both $\mathrm{Al} / \mathrm{CuO}(\sim 0.5 \mathrm{~ms})$ and $\mathrm{Al} /$ $\mathrm{AgFeO}_{2}$ (0.9 ms) implying a similar mechanism. ${ }^{51,52}$ Therefore, similar to $\mathrm{Al} / \mathrm{CuO},{ }^{37}$ the ignition/reaction mechanism of $\mathrm{Al} /$ $\mathrm{AgFeO}_{2}$ is summarized as follows: $\mathrm{AgFeO}_{2}$ releases $\mathrm{O}_{2}$ gas $(\sim 690$ 
Table 2 Combustion performance of mixed thermites of $\mathrm{Al} / \mathrm{AgFeO}_{2}$

\begin{tabular}{|c|c|c|c|c|}
\hline Thermites (stoichiometric) & $\begin{array}{l}\text { Peak pressure } \\
(\mathrm{kPa})\end{array}$ & $\begin{array}{l}\text { Pressurization } \\
\text { rate }\left(\mathrm{kPa} \mathrm{ms}^{-1}\right)\end{array}$ & $\begin{array}{l}\text { Burn time } \\
(\mathrm{ms})\end{array}$ & $\begin{array}{l}\text { Peak optical emission } \\
\text { (volts) }\end{array}$ \\
\hline $\mathrm{Al} / n \mathrm{CuO}$ & 226 & 2045 & 0.46 & 4.3 \\
\hline $\mathrm{Al} / \mathrm{Ag}_{2} \mathrm{O} / \mathrm{Fe}_{2} \mathrm{O}_{3}$ & 74 & 21 & 5 & 0.4 \\
\hline $\mathrm{Al} / \mathrm{AgFeO}_{2}$ & 325 & 6200 & 0.3 & 1 \\
\hline
\end{tabular}
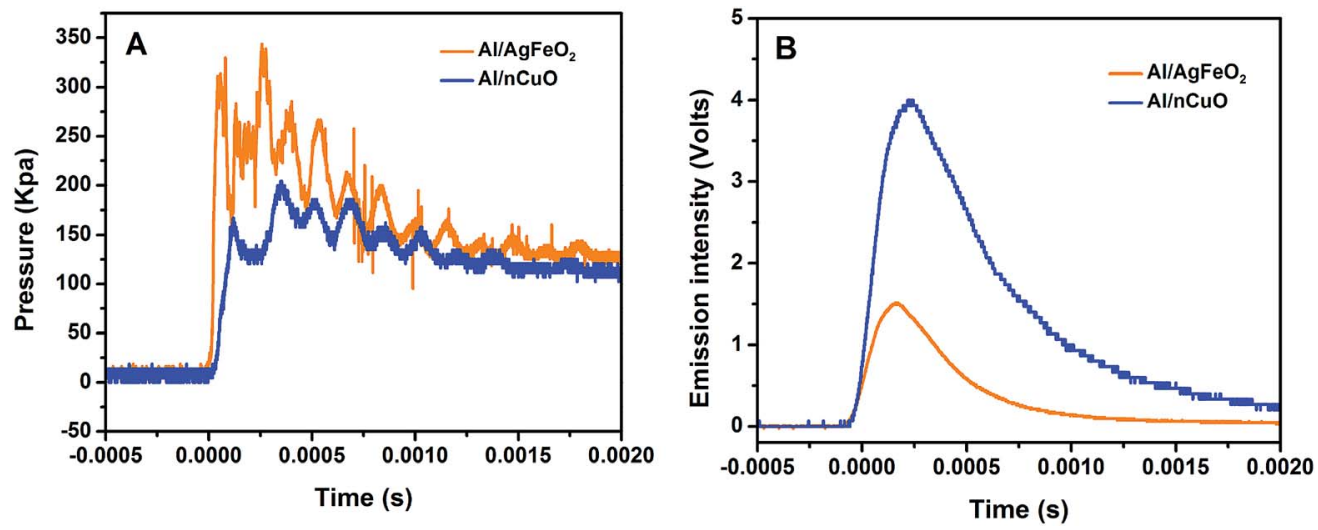

Fig. 6 Temporal pressure and optical behavior of $\mathrm{Al}_{\mathrm{AgFeO}}$ and $\mathrm{Al} / \mathrm{nCuO}$.

Table 3 Thermodynamic equilibrium predictions of $\mathrm{Al} / \mathrm{CuO}, \mathrm{Al} / \mathrm{Ag}_{2} \mathrm{O}$ and $\mathrm{Al} / \mathrm{Fe}_{2} \mathrm{O}_{3}$ thermites ${ }^{a}$

\begin{tabular}{llll}
\hline Thermite reaction & Adiabatic temperature $\left({ }^{\circ} \mathrm{C}\right)$ & $\begin{array}{l}\text { Gas production } \\
\left(\mathrm{mmol} \mathrm{g}^{-1}\right)\end{array}$ & Major gas species \\
\hline $2 \mathrm{Al}+3 \mathrm{CuO} \rightarrow \mathrm{Al}_{2} \mathrm{O}_{3}(\mathrm{l})+3 \mathrm{Cu}(\mathrm{l}, \mathrm{g})$ & 2570 & 5.4 & $\mathrm{Cu}$ \\
$2 \mathrm{Al}+3 \mathrm{Ag}_{2} \mathrm{O} \rightarrow \mathrm{Al}_{2} \mathrm{O}_{3}(\mathrm{l})+6 \mathrm{Ag}(\mathrm{l}, \mathrm{g})$ & 2163 & 4.3 & $\mathrm{Ag}$ \\
$2 \mathrm{Al}+\mathrm{Fe}_{2} \mathrm{O}_{3} \rightarrow \mathrm{Al}_{2} \mathrm{O}_{3}(\mathrm{l})+2 \mathrm{Fe}(\mathrm{l}, \mathrm{g})$ & 2862 & 1.4 & $\mathrm{Fe}$
\end{tabular}

${ }^{a}$ Assumptions: constant enthalpy and pressure with phase changes; without taking account of the oxide shell of aluminum. Data is taken from Fisher and Grubelich. ${ }^{50}$

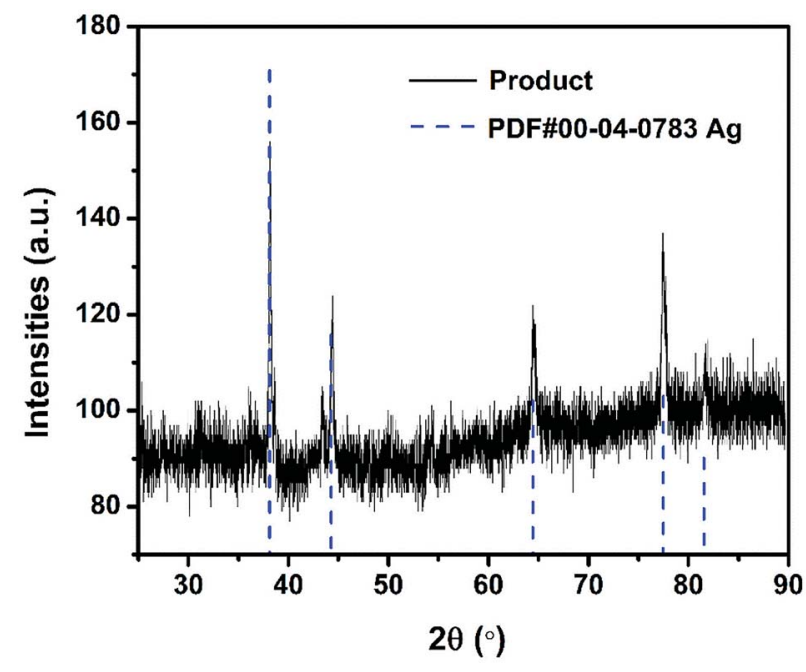

Fig. 7 The XRD pattern of $\mathrm{Al} / \mathrm{AgFeO}_{2}$ reaction product.
${ }^{\circ} \mathrm{C}$ ) and the aluminum core becomes mobile $\left(633^{\circ} \mathrm{C}\right)$; and the mixture ignites $\left(\sim 740^{\circ} \mathrm{C}\right.$, Fig. 5$)$ and the generated heat further promote the decomposition of $\mathrm{AgFeO}_{2}$ to pressurize the system.

Moreover, with a pressurization rate three times of $\mathrm{Al} / \mathrm{CuO}$, $\mathrm{Al} / \mathrm{AgFeO}_{2}$ yields a comparable result as prior work on $\mathrm{Al} /$ hollow-CuO ${ }^{25}$ or $\mathrm{Al} / \mathrm{KClO} 4 / \mathrm{CuO}^{37}$ which make $\mathrm{AgFeO}_{2}$ a powerful replacement owing to its simpler and cheaper preparation method.

Sullivan et al. ${ }^{2}$ has previously reported that $\mathrm{Al} / \mathrm{Ag}_{2} \mathrm{O}$ suffers a poor combustion performance in terms of both pressurization rate and peak pressure and incorporation of a small fraction of $\mathrm{CuO}$ into the $\mathrm{Al} / \mathrm{Ag}_{2} \mathrm{O}$ system improved its combustion performances extensively to even close to the reactivity of $\mathrm{Al} / \mathrm{CuO}$. An explanation was provided by Sullivan et al. that $\mathrm{CuO}$ addition can increase the reaction temperature and thus further enhance the performance of $\mathrm{Ag}_{2} \mathrm{O}$ as an oxidizer. Consistent with this reported result, $\mathrm{Al} / \mathrm{Ag}_{2} \mathrm{O}$ performs poorly in the combustion cell test due to an early release of $\mathrm{O}_{2} ;{ }^{2}$ however, $\mathrm{Fe}_{2} \mathrm{O}_{3}$ addition does not show much improvement to $\mathrm{Al} / \mathrm{Ag}_{2} \mathrm{O}$ system as $\mathrm{CuO}$ does. Instead of improving, $\mathrm{Fe}_{2} \mathrm{O}_{3}$ even weaken the combustion 


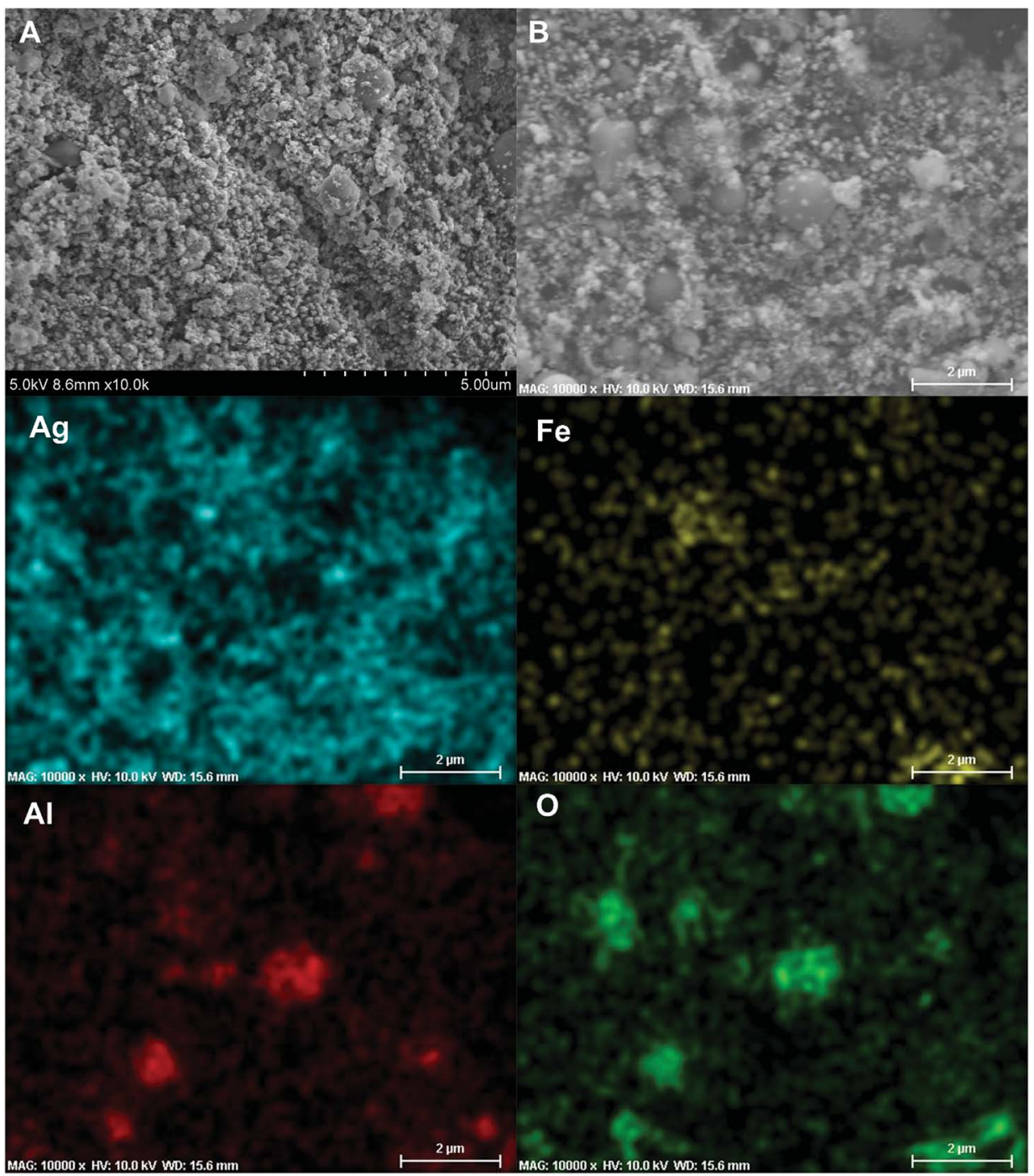

Fig. 8 Representative SEM images ( $\mathrm{A}$ and $\mathrm{B}$ ) of the $\mathrm{Al} / \mathrm{AgFeO}_{2}$ reaction product collected inside the combustion cell; $2 \mathrm{D}$ elemental mapping (Ag, $\mathrm{Fe}, \mathrm{Al}$ and $\mathrm{O}$ ) of (B) using EDS.

performance of $\mathrm{Al} / \mathrm{Ag}_{2} \mathrm{O}$ system considering $\mathrm{Al} / \mathrm{Ag}_{2} \mathrm{O} / \mathrm{Fe}_{2} \mathrm{O}_{3}$ features the worst pressurization rate and burn time. Thermodynamic equilibrium predictions of $\mathrm{Al} / \mathrm{CuO}, \mathrm{Al} / \mathrm{Ag}_{2} \mathrm{O}$ and $\mathrm{Al} /$ $\mathrm{Fe}_{2} \mathrm{O}_{3}$ thermites by Fischer and Grubelich ${ }^{2,27,50}$ are shown in Table 3 where we can see that both $\mathrm{CuO}$ and $\mathrm{Ag}_{2} \mathrm{O}$ should perform significantly better than $\mathrm{Fe}_{2} \mathrm{O}_{3}$ in terms of gas production. And this is consistent with our experimental data shown in Table 2. In detail, unlike $\mathrm{CuO}$ that can rapidly release $\mathrm{O}_{2}, \mathrm{Fe}_{2} \mathrm{O}_{3}$ cannot efficiently decompose and upon decomposition most of the oxygen is still fixed as solid $\mathrm{FeO},{ }^{37}$ which leads to its decomposition as the rate-limiting step for $\mathrm{Al} / \mathrm{Ag}_{2} \mathrm{O} / \mathrm{Fe}_{2} \mathrm{O}_{3}$ reaction and therefore weakened combustion performance. In fact, $\mathrm{Fe}_{2} \mathrm{O}_{3}$ has been introduced previously as a moderator to weaken the reactivities of $\mathrm{Al} / \mathrm{KMnO}_{4}{ }^{24}$ and $\mathrm{Al} / \mathrm{KClO}_{4} \cdot{ }^{37}$

$\mathrm{Al} / \mathrm{AgFeO}{ }_{2}$ significantly outperforms $\mathrm{Al} / \mathrm{Ag}_{2} \mathrm{O} / \mathrm{Fe}_{2} \mathrm{O}_{3}$ by a scale of almost 100 in pressurization rate and about 4 in peak pressure. The fact that $\mathrm{Al} / \mathrm{AgFeO}$ and $\mathrm{Al} / \mathrm{Ag}_{2} \mathrm{O} / \mathrm{Fe}_{2} \mathrm{O}_{3}$ share the exact same elemental compositions indicates molecularly incorporation of $\mathrm{Ag}_{2} \mathrm{O}$ into $\mathrm{Fe}_{2} \mathrm{O}_{3}$ outperforms the mechanically mixed
$\mathrm{Ag}_{2} \mathrm{O} / \mathrm{Fe}_{2} \mathrm{O}_{3}$ when they were employed as oxidizers in aluminum-based thermites.

The burn time of the thermite reactions measured in the combustion cell are shown in Table 2. Clearly, $\mathrm{Al} / \mathrm{AgFeO}_{2}$ features the shortest burn time which makes it the most violent thermite among the four examined. A direct comparison of the optical emission trace of $\mathrm{Al} / \mathrm{AgFeO}_{2}$ and $\mathrm{Al} / \mathrm{CuO}$ was shown in Fig. $6 \mathrm{~B}$. The $\mathrm{Al} / \mathrm{CuO}$ reaction has a four-times higher peak optical emission but $0.1 \mathrm{~ms}$ longer burn time compare with those of $\mathrm{Al} / \mathrm{AgFeO}_{2}$. This result indicates that $\mathrm{Al} / \mathrm{AgFeO}_{2}$ is a weaker heat generator than $\mathrm{Al} / \mathrm{CuO}$; but reacts more rapidly. In general, $\mathrm{AgFeO}_{2}$ is the best oxidizer among those four in the aluminum-based thermite system from both pressurization and optical emission perspectives.

\section{Post-combustion-product characterization}

It has been pointed out previously that the nature and dispersion of the products from a thermite combustion plays an important role in biocidal applications. ${ }^{27}$ XRD evaluation of 


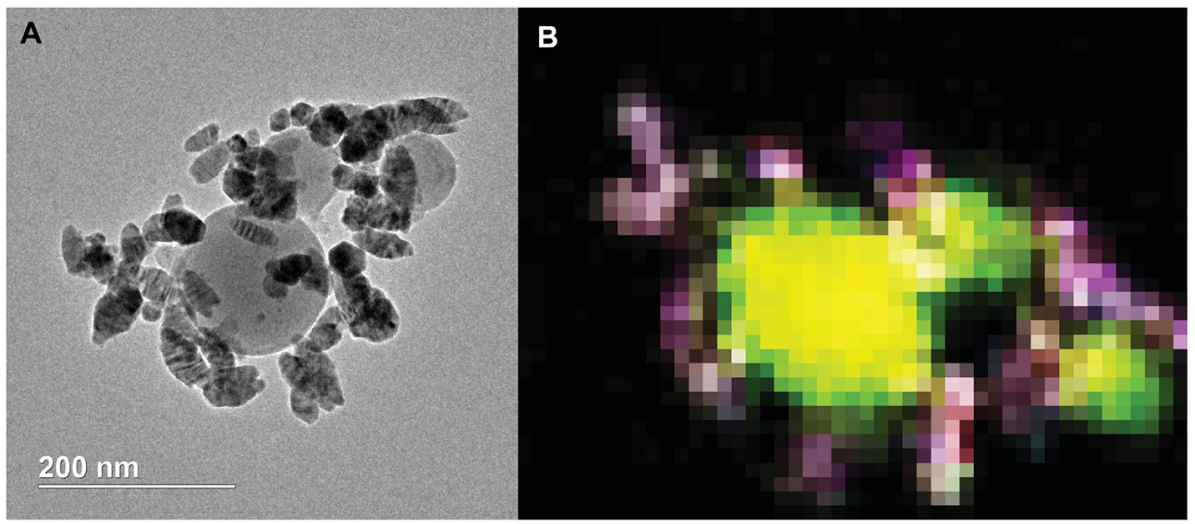

Fig. 9 TEM image (A) and 2D elemental mapping (B) of the $\mathrm{Al} / \mathrm{AgFeO}_{2}$ reaction product. Red represents Ag, blue represents Fe, yellow represents $\mathrm{Al}$ and green represents $\mathrm{O}$.

crystalline product species is shown in Fig. 7 and show no evidence of the parent starting materials, but five new strong peaks indexed to elemental silver are seen. The fact that no peak corresponding to $\mathrm{Al}_{2} \mathrm{O}_{3}$ or $\mathrm{Fe}$ was observed might suggest they are both amorphous.

For SEM evaluation of the reaction product a $7 \mathrm{~mm} \times 5 \mathrm{~mm}$ rectangular double-sided carbon tape was placed inside the combustion cell chamber. Two representative SEM images of the product were shown in Fig. 8A and B, there are mainly two populations of product particle sizes. One has relatively larger dimension and another with a dimension as small as $\sim 80 \mathrm{~nm}$.
2D elemental mapping using EDS shown in Fig. 8, indicate the larger spherical particles are $\mathrm{Al}_{2} \mathrm{O}_{3}$ while the smaller particles are Ag. This was also confirmed with 1D elemental line-scan coupled with elemental analysis shown in Fig. S3.† Most importantly for the application as a biocide, is that the smaller $\mathrm{Ag}$ particles randomly decorate the larger $\mathrm{Al}_{2} \mathrm{O}_{3}$ particles.

Overall, the intensity of iron signal is the weakest among those four elements under EDS mapping implying the random distribution of iron.

TEM of the reaction product along with an EDS elemental mapping result is shown in Fig. 9. As can be seen, there are two
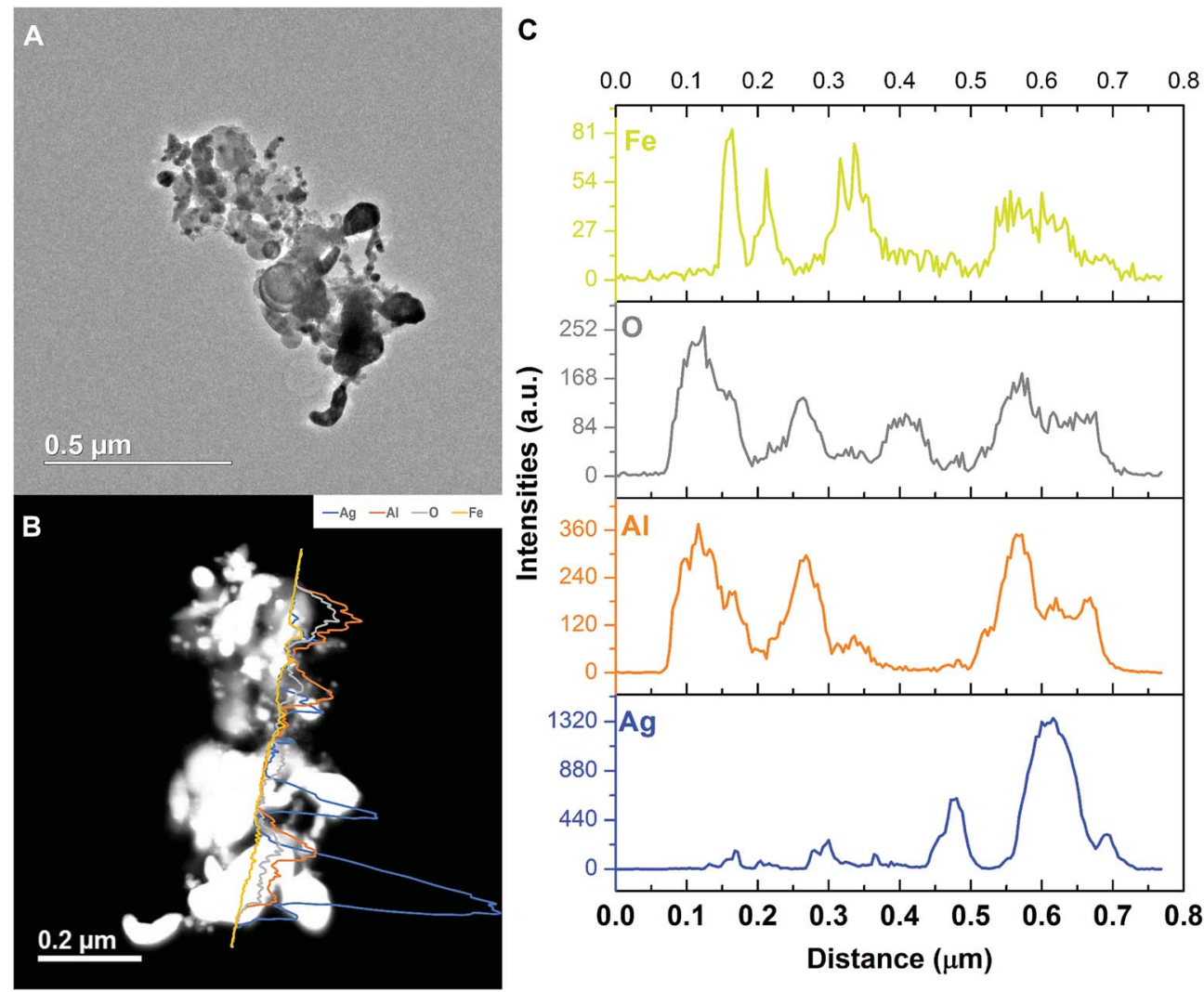

Fig. 10 Representative TEM image and the corresponding EDS line-scan data of the $\mathrm{Al} / \mathrm{AgFeO}_{2}$ reaction product. 
different types of particles similar to the SEM result. One has a spherical shape with a relatively larger particle size and low contrast; another has a spherical/oval shape with smaller size and dark contrast. In the EDS elemental mapping, red represents silver, blue iron, yellow aluminum and green oxygen. Clearly, the three larger spherical particles are $\mathrm{Al}_{2} \mathrm{O}_{3}$. Since the mixing of red and blue gives purple, it is reasonable to conclude that the silver and iron positions are mostly overlapped. It could mean a formation of $\mathrm{Ag}-\mathrm{Fe}$ alloy; however, the SEM results indicate the iron signal is much weaker and always appears with the presence of both aluminum and oxygen signals. To clarify this speculation, an EDS line-scan analysis was employed, and the result will be discussed below. It should also be noted that some white pixels were found in the purple area, implying the presence of oxygen (green plus red and blue equals to white). Thus, those silver- and iron-containing particles might be partially oxidized that could be a result from handling the product in air.

As we can see from the EDS line-scan result shown in Fig. 10, excerpt for the small oxygen signal peak at $\sim 0.4 \mu \mathrm{m}$, the aluminum and oxygen signals are almost synchronous in positions indicating $\mathrm{Al}_{2} \mathrm{O}_{3}$. Like the SEM EDS mapping result, iron is the weakest among all four elements. It overlaps with aluminum and silver, respectively, implying the iron is randomly distributed and excluding the hypothesis of $\mathrm{Ag}-\mathrm{Fe}$ alloy formation.

Comparing these two representative TEM images Fig. 9A and 10A, the morphologies of the silver particles are quite different. The ones in Fig. 9A are nanosized with spherical/oval shapes and are decorated on/near the $\mathrm{Al}_{2} \mathrm{O}_{3}$ surface that suggests silver product had vaporized and re-condensed. ${ }^{2}$ This mechanism is beneficial to biocidal applications due to the wide distribution of small sized silver particles during the violent combustion event. As to the one in Fig. 10A, particles at the bottom right with oddly shapes clearly underwent some sintering. Those results are consistent to a previously reported sintering reaction mechanism of Al-based thermites. ${ }^{53,54}$ However, it seems much less reactants were following the sintering mechanism according to the SEM image shown in Fig. 8 where the majority of silver product has small particle size and distributed randomly.

\section{Conclusions}

In this study, the $\mathrm{AgFeO}_{2}$ was prepared via a wet-chemistry method to yield phase pure $\sim 40 \mathrm{~nm}$ particles. The decomposition pathways of $\mathrm{AgFeO}_{2}$ were found to depend on heating rates: decomposition to $\mathrm{Ag}, \mathrm{O}_{2}$ and $\mathrm{Fe}_{2} \mathrm{O}_{3}$ at $\sim 600{ }^{\circ} \mathrm{C}$ at low heating rate and direct decomposition $\sim 685{ }^{\circ} \mathrm{C}$ at high heating rates.

The ignition of $\mathrm{Al} / \mathrm{AgFeO}_{2}$ was found to slightly higher than the oxygen release temperature and thus with a similar mechanism to $\mathrm{Al} / \mathrm{Fe}_{2} \mathrm{O}_{3}$ although ignites at a much lower temperature. Fast video imaging indicates a fine smoke dispersing particle.

Combustion cell test showed that $\mathrm{Al} / \mathrm{AgFeO}{ }_{2}$ outperformed other thermites in maximum pressure, pressurization rate and burn time. Moreover, with a pressurization rate three times and
$5 \%$ less oxygen content of $\mathrm{Al} / \mathrm{CuO}, \mathrm{Al} / \mathrm{AgFeO}{ }_{2}$ yields a comparable result as to $\mathrm{Al} /$ hollow-CuO or $\mathrm{Al} / \mathrm{KClO}_{4} / \mathrm{CuO}$. The fact that $\mathrm{Al} / \mathrm{AgFeO} \mathrm{O}_{2}$ and $\mathrm{Al} / \mathrm{Ag}_{2} \mathrm{O} / \mathrm{Fe}_{2} \mathrm{O}_{3}$ share the exact same elemental compositions but feature the highest and lowest pressurization rate, respectively, indicates molecularly incorporation of $\mathrm{Ag}_{2} \mathrm{O}$ into $\mathrm{Fe}_{2} \mathrm{O}_{3}$ outperforms the mechanically mixed $\mathrm{Ag}_{2} \mathrm{O} / \mathrm{Fe}_{2} \mathrm{O}_{3}$ when they were employed as oxidizers in aluminum-based thermites. Post combustion products indicate the formation of elemental silver nanoparticles $(\sim<80 \mathrm{~nm})$ decorating larger $\mathrm{Al}_{2} \mathrm{O}_{3}$ and is this bioavailable.

\section{Conflicts of interest}

There are no conflicts to declare.

\section{Acknowledgements}

Support for this work comes from the Defense Threat Reduction Agency.

\section{References}

1 E. R. Blatchley, A. Meeusen, A. I. Aronson and L. Brewster, J. Environ. Eng. Div. (Am. Soc. Civ. Eng.), 2005, 131, 1245-1252.

2 K. T. Sullivan, C. W. Wu, N. W. Piekiel, K. Gaskell and M. R. Zachariah, Combust. Flame, 2013, 160, 438-446.

3 M. Schoenitz, T. S. Ward and E. L. Dreizin, Proc. Combust. Inst., 2005, 30, 2071-2078.

4 T. S. Ward, W. L. Chen, M. Schoenitz, R. N. Dave and E. L. Dreizin, Acta Mater., 2005, 53, 2909-2918.

5 K. T. Sullivan, N. W. Piekiel, S. Chowdhury, C. Wu, M. R. Zachariah and C. E. Johnson, Combust. Sci. Technol., 2011, 183, 285-302.

6 W. Zhou, M. W. Orr, G. Jian, S. K. Watt, V. T. Lee and M. R. Zachariah, Chem. Eng. J., 2015, 279, 578-588.

7 W. B. Zhou, M. W. Orr, V. T. Lee and M. R. Zachariah, Chem. Eng. Sci., 2016, 144, 39-47.

8 F. T. Tabit and E. Buys, Int. J. Food Microbiol., 2010, 140, 207213.

9 S. S. Zhang, C. Badiola, M. Schoenitz and E. L. Dreizin, Combust. Flame, 2012, 159, 1980-1986.

10 S. S. Zhang, M. Schoenitz and E. L. Dreizin, J. Phys. Chem. Solids, 2010, 71, 1213-1220.

11 S. S. Zhang, M. Schoenitz and E. L. Dreizin, J. Phys. Chem. C, 2010, 114, 19653-19659.

12 H. Wang, G. Jian, W. Zhou, J. B. DeLisio, V. T. Lee and M. R. Zachariah, ACS Appl. Mater. Interfaces, 2015, 7, 17363-17370.

13 E. L. Dreizin, Prog. Energy Combust. Sci., 2009, 35, 141-167.

14 C. Rossi, K. Zhang, D. Esteve, P. Alphonse, P. Tailhades and C. Vahlas, J. Microelectromech. Syst., 2007, 16, 919-931.

15 R. A. Yetter, G. A. Risha and S. F. Son, Proc. Combust. Inst., 2009, 32, 1819-1838.

16 N. H. Yen and L. Y. Wang, Propellants, Explos., Pyrotech., 2012, 37, 143-155.

17 X. Z. Wang, T. Wu and M. R. Zachariah, J. Phys. Chem. C, 2017, 121, 147-152. 
18 G. Jian, N. W. Piekiel and M. R. Zachariah, J. Phys. Chem. C, 2012, 116, 26881-26887.

19 G. Q. Jian, S. Chowdhury, K. Sullivan and M. R. Zachariah, Combust. Flame, 2013, 160, 432-437.

20 K. S. Martirosyan, J. Mater. Chem., 2011, 21, 9400-9405.

21 H. Y. Wang, J. B. Delisio, G. Q. Jian, W. B. Zhou and M. R. Zachariah, Combust. Flame, 2015, 162, 2823-2829.

22 X. Z. Wang, W. B. Zhou, J. B. DeLisio, G. C. Egan and M. R. Zachariah, Phys. Chem. Chem. Phys., 2017, 19, 1274912758.

23 K. Zhang, C. Rossi, G. A. A. Rodriguez, C. Tenailleau and P. Alphonse, Appl. Phys. Lett., 2007, 91, 113117.

24 A. Prakash, A. V. McCormick and M. R. Zachariah, Nano Lett., 2005, 5, 1357-1360.

25 G. Q. Jian, L. Liu and M. R. Zachariah, Adv. Funct. Mater., 2013, 23, 1341-1346.

26 L. Shen, G. Li, Y. Luo, K. Gao and Z. Ge, Sci. China: Chem., 2014, 57, 797-802.

27 G. Jian, S. Chowdhury, J. Feng and M. R. Zachariah, presented in part at the 8th U. S. National Combustion Meeting, Utah, May 19-22, 2013.

28 B. K. Little, E. J. Welle, S. B. Emery, M. B. Bogle, V. L. Ashley, A. M. Schrand and C. M. Lindsay, J. Phys.: Conf. Ser., 2014, 500.

29 T. Wu, A. SyBing, X. Z. Wang and M. R. Zachariah, J. Mater. Res., 2017, 32, 890-896.

30 T. Wu, X. Wang, J. B. DeLisio, H. Wang and M. R. Zachariah, Combust. Flame, 2017, 191, 335-342.

31 C. Farley and M. Pantoya, J. Therm. Anal. Calorim., 2010, 102, 609-613.

32 T. Wu, X. Z. Wang, J. B. DeLisio, S. Holdren and M. R. Zachariah, Carbon, 2018, 130, 410-415.

33 W. B. Zhou, J. B. DeLisio, X. Y. Li, L. Liu and M. R. Zachariah, J. Mater. Chem. A, 2015, 3, 11838-11846.

34 M. Comet, G. Vidick, F. Schnell, Y. Suma, B. Baps and D. Spitzer, Angew. Chem., Int. Ed., 2015, 54, 4458-4462.

35 X. L. Hu, W. B. Zhou, X. Z. Wang, T. Wu, J. B. Delisio and M. R. Zachariah, J. Nanopart. Res., 2016, 18, 214.

36 X. L. Hu, J. B. Delisio, X. Y. Li, W. B. Zhou and M. R. Zachariah, Adv. Eng. Mater., 2017, 19, 1500532.
37 C. W. Wu, K. Sullivan, S. Chowdhury, G. Q. Jian, L. Zhou and M. R. Zachariah, Adv. Funct. Mater., 2012, 22, 78-85.

38 W. B. Zhou, J. B. DeLisio, X. Z. Wang and M. R. Zachariah, Combust. Flame, 2017, 177, 1-9.

39 Y. Aly, S. Zhang, M. Schoenitz, V. K. Hoffmann, E. L. Dreizin, M. Yermakov, R. Indugula and S. A. Grinshpun, Combust. Flame, 2014, 161, 303-310.

40 C. L. He, J. H. Zhang and J. M. Shreeve, Chem.-Eur. J., 2013, 19, 7503-7509.

41 C. E. Johnson and K. T. Higa, MRS Proc., 2013, 1521.

42 O. Mulamba, E. M. Hunt and M. L. Pantoya, Biotechnol. Bioprocess Eng., 2013, 18, 918-925.

43 J. B. Delisio, X. L. Hu, T. Wu, G. C. Egan, G. Young and M. R. Zachariah, J. Phys. Chem. B, 2016, 120, 5534-5542.

44 T. Wu, P. Y. Zavalij and M. R. Zachariah, Powder Diffr., 2017, 32, 261-264.

45 E. Rentz Do Comm Cnmo, J. Nutr. Environ. Med., 2009, 13, 109-118.

46 J. R. Morones, J. L. Elechiguerra, A. Camacho, K. Holt, J. B. Kouri, J. T. Ramirez and M. J. Yacaman, Nanotechnology, 2005, 16, 2346-2353.

47 A. B. Smetana, K. J. Klabunde, G. R. Marchin and C. M. Sorensen, Langmuir, 2008, 24, 7457-7464.

48 B. R. Clark and M. L. Pantoya, Phys. Chem. Chem. Phys., 2010, 12, 12653-12657.

49 R. Russell, S. Bless and M. Pantoya, J. Energ. Mater., 2011, 29, 175-192.

$50 \mathrm{~S}$. H. Fischer and M. C. Grubelich, presented in part at the 24th International Pyrotechnics Seminar, The International Pyrotechnics Society, Monterey, California, USA, 1998.

51 K. Sullivan and M. R. Zachariah, J. Propul. Power, 2010, 26, 467-472.

52 L. Zhou, N. Piekiel, S. Chowdhury and M. R. Zachariah, J. Phys. Chem. C, 2010, 114, 14269-14275.

53 K. T. Sullivan, W. A. Chiou, R. Fiore and M. R. Zachariah, Appl. Phys. Lett., 2010, 97, 133104.

54 K. T. Sullivan, N. W. Piekiel, C. Wu, S. Chowdhury, S. T. Kelly, T. C. Hufnagel, K. Fezzaa and M. R. Zachariah, Combust. Flame, 2012, 159, 2-15. 